\title{
十勝沖地震を批判する
}

\section{高木＼cjkstart聖 \\ Comment on the Off Tokachi Earthquakes}

\author{
by \\ Sei Takagi \\ Meteorological Research Institute, Tokyo
}

(Received May 31, 1973)

\begin{abstract}
Earthquakes which occur between the Japanese north-eastern coast and the Japan Trench are called Off Tokachi earthquakes. These earthquakes contain many problems for Plate Tectonics. This theory asserts that these earthquakes are produced by direct pressure to the Trench. But, the mechanisms of these earthquakes go against this. theory. For example, Fig. 1 gives the radiation pattern classified by the quadrant theory, but observations at Hachinohe, Yamagata, Matsushiro, Niigata, Utsunomiya, Hamada and Abashiri go against. this type. Fig. 2 shows the radiation pattern of the same earthquake as in Fig. 1, but classified by the conical theory. This conical pattern is far more excellent than the quadrant type of Fig. 1. The belowright figure shows the underground structure for making this pattern. Similarly, Fig. 3 shows the radiation pattern classified by the quadrant theory, but obervations at Aomori, Akita, Wazima, Sumoto, Okayama, Koochi, Shimizu, Amamiooshima and Okinawa go against this quadrant type. So, this pattern also is not quadrant type. Yet, Fig. 4 gives the radiation pattern of the same earthquake as in Fig. 3, classified by the conical theory. This is far more excellent than the quadrant type in Fig. 3. The below-right figure shows the underground structure for making this pattern. Also, Fig. 5 is the radiation pattern classified by the quadrant theory, but observations at Takada, Matsushiro, Toyama, Kanazawa, Kyoto and Owase go against the quadrant type. So, this pattern also is not quadrant type. Fig. 6 . shows the radiation pattern of the same earthquake as in Fig. 5, but classified by the conical theory. This conical pattern is far more excellent than the quadrant type in Fig. 5. The below-right figure shows the underground structure for making this pattern.
\end{abstract}

These quadrant types are classified by Dr. Masaji Ichikawa. 


\section{1. 序説}

北海道物よび東北地方の東岸と日本海瑇との間に起る地震の初動分布は, 従来, 特異な型をし ているものが多かった。筆者も，かねがね，本格的な調查をしたいと思っていたが，このあたり は，地下構造が不明なのと，震央も地震の深さも，はっきりとは決まらない所であったので，詳 細な調査ができなかった。やっと最近になって, I.S.C. (International Seismological Centre) の資料がそろい，最近は，外国でも，初動方向の sense を記入するよらになったので，この助 けを借りて，調査をしな括してみた。

その結果, このあたりの Mohorovicic 層は, 異常な形をしていると考光なくてはならない し，地震機構は断層型でないことも，はっきりした。しかも，このあたりは，今，流行の海底拡 大説や plate 説に取っては，地殼の落ち込む所であり，断層型の地震が起らなければならない 所であるが，実際の現象は，そらなっていない。したがって，海底拡大説や plate 説，断層説 等は，観念的な遊びに過ぎないことがわかる。

\section{2. 十勝沖地震は断層型ではない}

ここで十勝沖地震とゆうのは, 北海道南東岸就よび青森県東岸, 岩手県東岸と, 日本海溝との 間に起る地震の総称とする。

ごく最近 (昭和43年) に起った十勝沖地震については, 金森博雄 (1971年) や長宗留男 (1971 年）等の調査があるが，いずれも，不完全な調査である。市川政治（1969年）の調査は，これら に較べると，比較的良好であるが，まだ不十分である。

Table 1 は，以下に対象となる地震の表である。震央要素は気象庁調査のものと，I.S.C. 調 查のものとを併記した。発震機構は筆者のものと, 市川のものと, 金森のものとを列記した。

Fig. 1 は，昭和43年 (1968年) 5 月16日 9 時 48 分の十勝沖地震の初動分布である。この地震 は，死者 49 人を出し，津波もめって，最大の所では 5 メートルもあった。地震の大きさも，大 正12年 (1923年) の関東大地震と同じくらいである。この地震は, plate 説の巻き込夕の部分に 起った地震であったから，多くの人々によって調査された。外国でも初動方向がよく観測され た。Fig.1 の左上の stereograph の図は，I.S.C.の資料を stereograph に plotしたもので ある。中央が震央になっている。I.S.C.の資料は，震央を通る子午線の北を基準にして，時針 回りに Az. (観測点の方位) がきめてあり, delta (震央距離) は度単位できめてあるので, 震 央中心の stereograph を用いて plotすると, 作業が簡単である。その上, 地球上の円がstereograph の上でも円になるので，つごうがよい。

Fig. 1 の左下の図は, 金森（前出）の調査である。この図の中心から南の方へ，たくさんの 引波が記入してめる。左上の図を見ればわかるょうに，I.S.C.の資料には，このような引波は 観測されていない。中央の日本付近の図を見ても，南には引波がないのである。dataを作った のかも知れない。それゆ光，この図を見て4 象限型の初動分布とみなすのはまちがいである。

長宗 (前出)の調査も，金森と同じょらな機構になっているが，南の引波を記入していない。ま た，西日本の引波は neglect几てある。この引波がはいると，4像限型にならないからである。 市川（前出）の調查は, Fig.1 の右下の図である。これは Wulf Netを用いている。Wulf Net という名前の由来はよくわからないが，下半球を上半球の対称点に記入したものである。 4 象限型を調查するには，つごらがいいかも知礼ないが，実体図ではないから，以下に批判する 


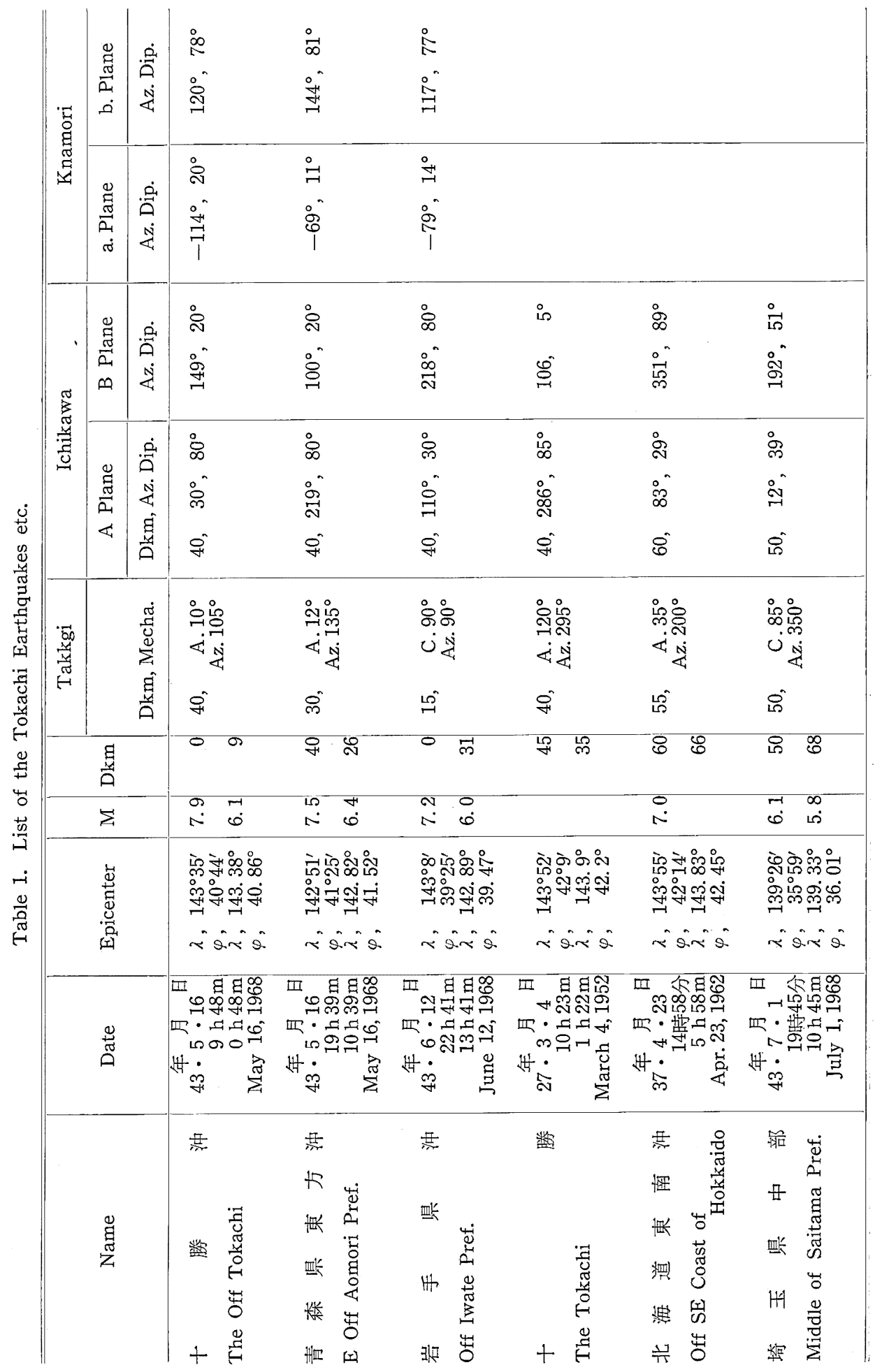



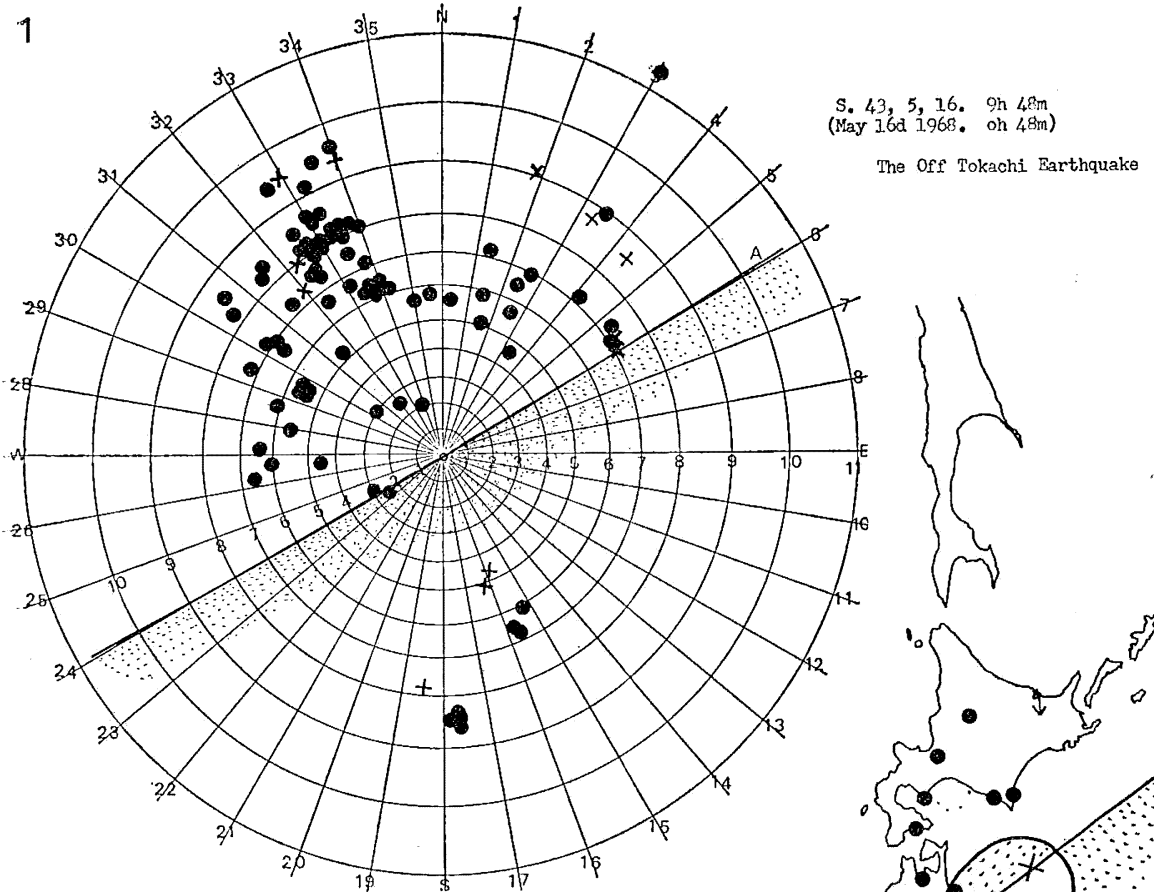

- compression (push)

$\times$ dilatation (pulz)

Xepicenter

: dilatation area

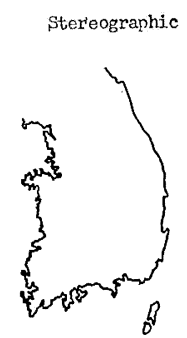

Net
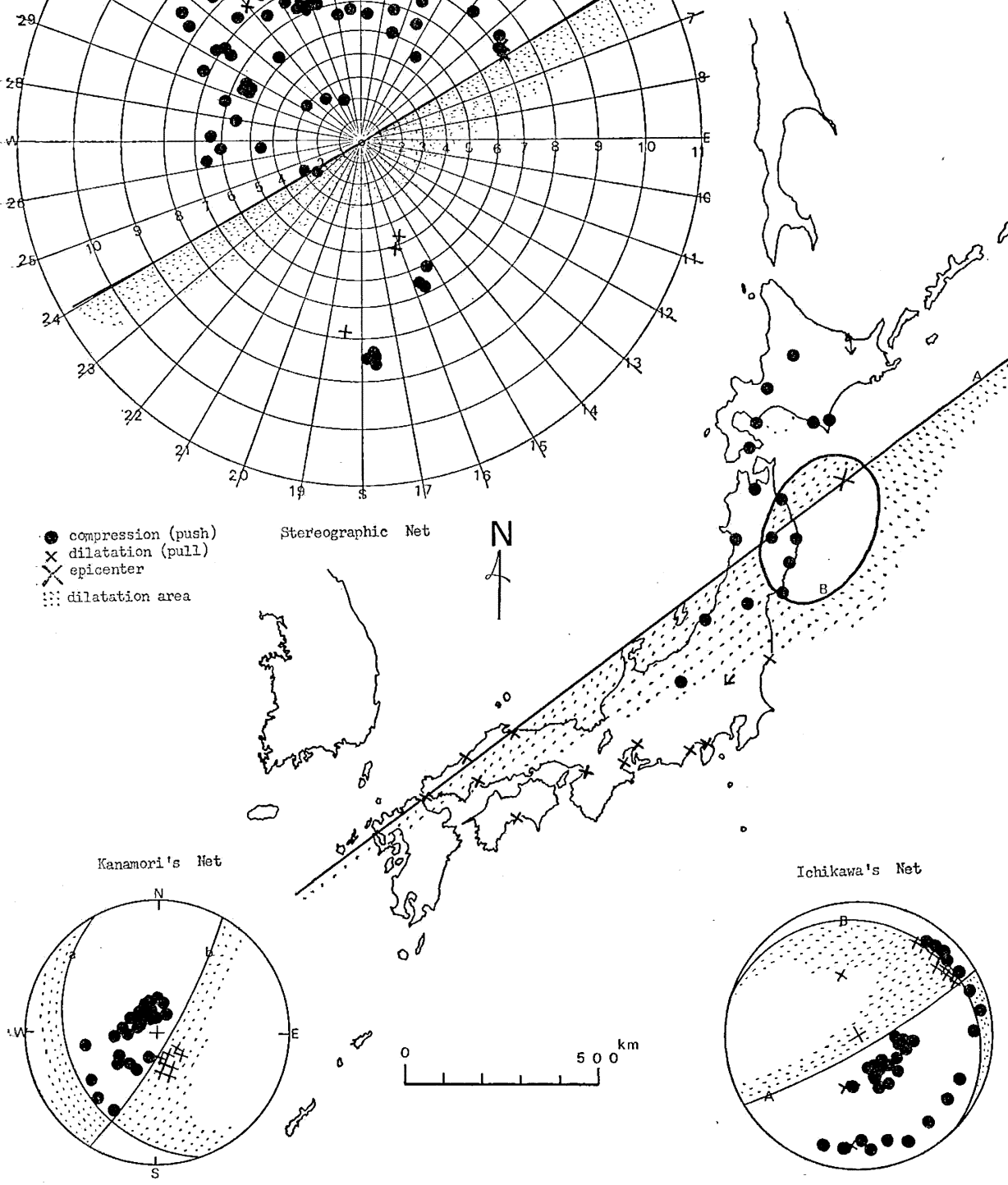

Fig. 1. The Off Tokachi Earthquake at about 9 o'clock of May 16, 1968: This radiation pattern is the quadrant type. The upper left figure represents the distribution of first motions of the world observations plotted on a stereographic map. The central figure shows the radiation pattern of the Japanese neighbourhood. The under left figure is Kanamori's stereographic net for the radiation pattern. The under right figure is Ichikawa's Wulf net. Ichikawa's net is more excellent than Kanamori's. But observations at Hachinohe, Yamagata. Niigata, Matsushiro, Utsunomiya, Hamada and Abashiri are against the quadrant tvpe. So this radiation pattern is not 


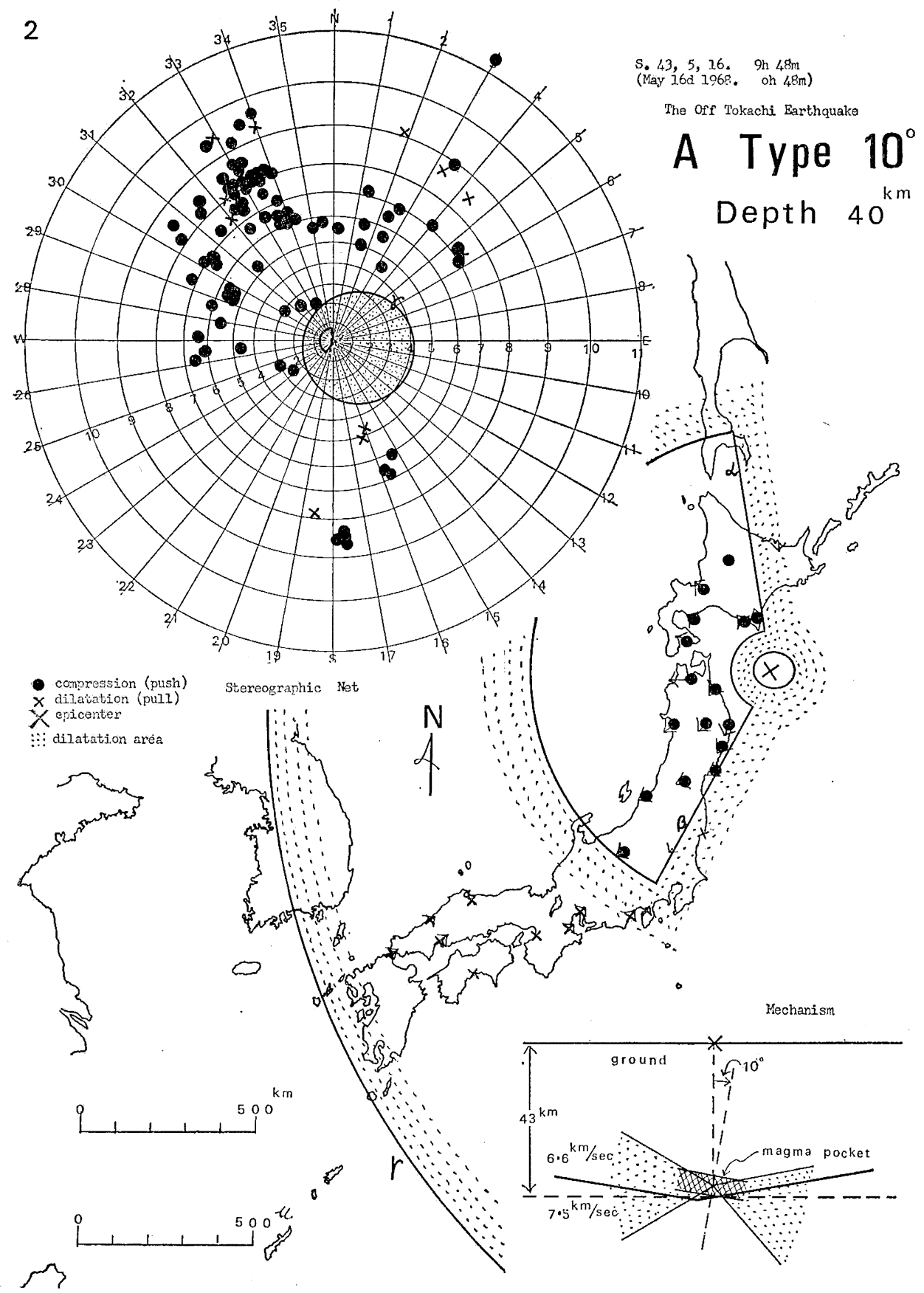

Fig. 2. The same earthquake as in Fig. 1: This radiation pattern is conical type. The upper left figure shows the distribution of initial motions of the world observations plotted on a stereographic map. The central figure shows the radiation pattern of the Japanese neighbourhood. This pattern is far more excellent than Fig. 1. The lower right figure shows the underground structure for making this pattern. 
ように，まちがい易い欠点がある。それゆえ，筆者は stereograph を用いて，実体に近い記入 方法を採用した。市川は, この地震の深さを $40 \mathrm{~km}$ として調査している。しかし, 気象庁技術 報告には, 市川自身 $0 \mathrm{~km}$ としている。この調查に従って, 日本付近の nodal line を描くと, Fig.1 の中央の図となる。山形, 新潟, 松代, 網走, 浜田の観測が合致していない。また, 八 戸, 盛岡, 石巻の観測も, 厳密にい壳ば, はずれている。このように, 震央に近い所が合致しな いということは，この機棈（4象限型）に区分することができないといらことである。Fig.1の 左上の図には，市川の nodal line を記入して掠いた。金森の nodal line は，外国の観測さ兄 も，らまく区分していないことがわかるであるう。

Fig. 2 は, Fig. 1 と, まったく同じものであるが，岩しょら爆発説の立場から，筆者が区分 したものである。岩しょう爆発型の初動分布については, 筆者の論文の内, 震源第 2 報 (験震時 報第14巻, 昭25）から震源第14報（験震時報第19巻, 昭30）ぬでを参照して頂きたい。地震の深 さは $40 \mathrm{~km}$ とした。機構は, A Type (非対称押円錐型) $10^{\circ}$ となっている。主軸（頂角 $140^{\circ}$ の 円錐の軸）の向きは，北より時針方向に $105^{\circ}$ とっている。ほとんど，はずれる観測点むなく， らまく区分されている。Fig.1 と比較すると格段の相違があることがわかる。右下の図は，震 源付近の内部構造と発震機構の図である。縦も横も同じ縮尺にしてある。このような内部構造と 発震機構のもとでは, Fig.2 の中央の nodal lineとなり, また, 左上の stereographの nodal line になることを示している。これについては, 次節で詳しく述べる。

Fig. 3 は昭和43年 (1968年) 5 月16日, 19時 39 分に起った青森県東方沖地震の初動分布であ る。この地震は, 前記十勝沖地震の10時間後に起った大きな地震で, 関東大地震と同じぐらい か，すこし少さいていどの地震であった。しかも，十勝沖地震の西北 $100 \mathrm{~km}$ ぐらいの所に起っ ている。もし, plate 説の言うょうに, plateの落ち込みによる歪力によって, 地震が断層とし て起るものならば，わずか10時間後に歪 energy の蓄積が，大地震になるほどたるるとは考兄 られない。松沢武雄 (168年) も, “大地震の続発”といら論文の中で, 同様の意見を述べてい る。それゆ光，この不合理を説明するために，金森（前出）の調査が始るったものと思われる。 金森は, この地震を, 前記十勝沖地震にひっぱられて2 次的に起ったとしているので, 初動分布 は4象限型にならなければならない。Fig.3 の左下の図が金森の調査であるが，この通りだと すると, 日本付近の初動分布は，らまく区分でさない。それゆ光，金森の考光は，現象に根拠を おいていないことになる。

同じ 4 象限型の立場に立った市川（前出）の調査は，Fig.3 の右下の図である。それに従っ て日本付近の初動分布を区分したのが，Fig.3 の中央の図である。青森，秋田，輪島の引波が はずれている。これらは震央付近の観測であるので,一つでも二つでも，はずれるということ は，現象をらまく区分しているとは言えないのである。他にこれらを含めて，らまく区分出来る 機構がある場合には，市川の調査は否定される。

外国の資料は，Fig.3 の左上の stereograph の図である。この nodal line は市川の調査に よるものである。外国では, Fig. 1 と Fig. 3 とでは, 押, 引の分布が，すっかり逆になってい る。したがって, 金森の調査も市川の調查も, Fig.1 の断層と Fig.3 の断層とは, 互いに逆方 向の断層となっていて, plate 説には, つごうが悪かったのである。それゆ光，金森の説明が 提出されたが，不適当な説明のように思われるところから，山川宜男 (1972) 等は海洋の水圧で 説明をこころみている。しかし，この地震は，初動分布からみると，断層型ではないのだから， これらの説明は無意味なものになっている。 
Fig. 4 は同じ地震を岩しょら爆発型に区分したものである。地震の深さは $30 \mathrm{~km}$ とし; 非対 称押円錐型 $120^{\circ}$ となっている。主軸の方向は，北より時針方向に $135^{\circ}$ である。Fig. 4 の左上 図は，I.S.C.の資料を stereograph に記入したもので，Fig.3 の左上図と同じものであるが， 初動分布の区分は非対称押円錐型 $120^{\circ}$ そなっている。

Fig. 3 と Fig.4 とを比較すると，外国の資料は，どちらも同じょうに，らまく区分されてい るが，日本付近の初動分布は，Fig.4 の方が，はるか浣全に近い型で区分されている。した がって，断層型に区分したことが，まらがいであったことが；わかるであろう。

Fig. 5 は，昭和43年 (1968年) 6 月12日22時41分頃の岩手県沖の地震である。地震の大きさ は，関東大地震より小さく，北伊豆地震より大きい。Fig. 5 の左上の図は，外国の資料である が，Fig.1 の左上の図と，㴗とど同じであるが，日本付近はFig.1 とは非常にちがってい る。Fig. 5 の左下の図は金森の調査であるが，これは，外国の資料も，うまく区分されていな いし，日本付近は全々合致していない。非常に観念的な調査である。市川の調査は右下に記入 してある。この地震の深さも，市川は $0 \mathrm{~km}$ とているが，実際には $40 \mathrm{~km}$ として，調査した ということであった。それによると，Fig.5 の中央の区分になる。東北地方の引波の部分は， うまく区分されているが，高田，松代，富山，金沢，京都の押波が，らまく区分されていない。

Fig. 5 は，同じ地震を岩しょう爆発型に区分したものである。湮とんど例外なく，らまく区 分されている。これは, 引円錐型の軸が $90^{\circ}$ 傾いているもので, 地表に平行になっている。主軸 の方向は東西方向である。地震の深さは $15 \mathrm{~km}$ としてある。これについては, 次節に詳しく述 ベるが，内部構造は Fig. 6 の右下の図となっている。左上の stereograph による外国の資料 も矛盾なく区分されている。

Fig. 5 と比較すると，Fig.6 の方が格段に現象に忠実であることがわかる。したがって，こ の地震も 4 象限型に区分できないと言える。

Fig. 7 は, 昭和27年 (1952年) 3 月 4 日10時23分頃の十勝沖地震の初動分布を, 断層型に区 分したものである。この地震は, 関東大地震よりも大きい地震であった。日中の地震であったか ら，被害がすくなかったが，死者28名，津波も釧路を和そった。この頃は，まだ，外国では，初 動分布の重要性がわからなかった時代であったから，外国の初動の観測資料は非常に少ない。そ れゆえ，外国資料から地震機構を決めることは無理であるが，日本付近の資料は，はっきりして いる。この地震の深さを, 気象庁は $45 \mathrm{~km}$, I.S.C. は $35 \mathrm{~km}$, 市川は $40 \mathrm{~km}$ としている。Fig.7 の左上の stereograph の nodal line は市川の調査によるものである。図の中央の日本付近の nodal line छ市川の調查によるものである。震央付近の釧路, 带広, 網走は, この区分に合っ ていない。ほかに，もっと現象に合致した区分方法がある場合は，市川の区分は否定されること になる。

Fig. 8 は, 同じ地震を岩しょら爆発型に区分したものである。地震の深さは $40 \mathrm{~km}$ とし, 非 対称押円錐型の主軸が $120^{\circ}$ 傾いているもので, 㶢の軸の方向は北から時針回りに $295^{\circ}$ となって いる。これは Fig. 4 と同型であるが，軸の方向が逆になっている。Fig.7 と比較すると, Fig. 8 の方が，現象に忠実である。やはり，断層型を主張することは；無理だと思う。

Fig. 9 は，昭和37年（1962年） 4 月23日14時 58 分の北海道東南沖の地震の初動分布を断層型 に区分したものである。この地震は関東大地震と同じぐらいの大きな地震であったが，大きな被 害はなかった。10年前の前記地震と, ほとんど同じような所に起っている。地震の深さは, 気象 庁の調査では $60 \mathrm{~km}$ であるが，I.S.C.は $66 \mathrm{~km}$ としている。市川の調査は $60 \mathrm{~km}$ としてある。 


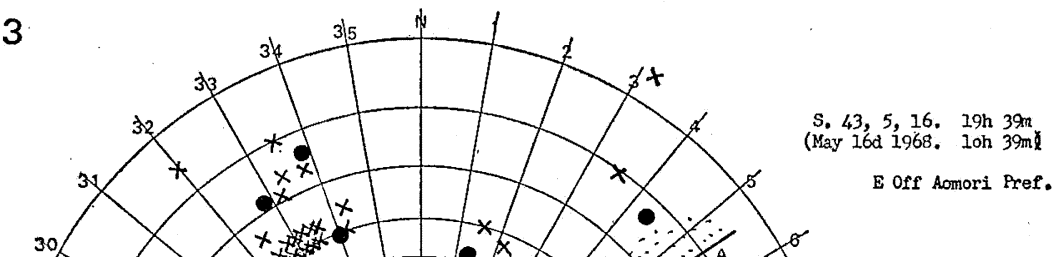

$\underset{X}{X}$ epicenter

: dilatation area
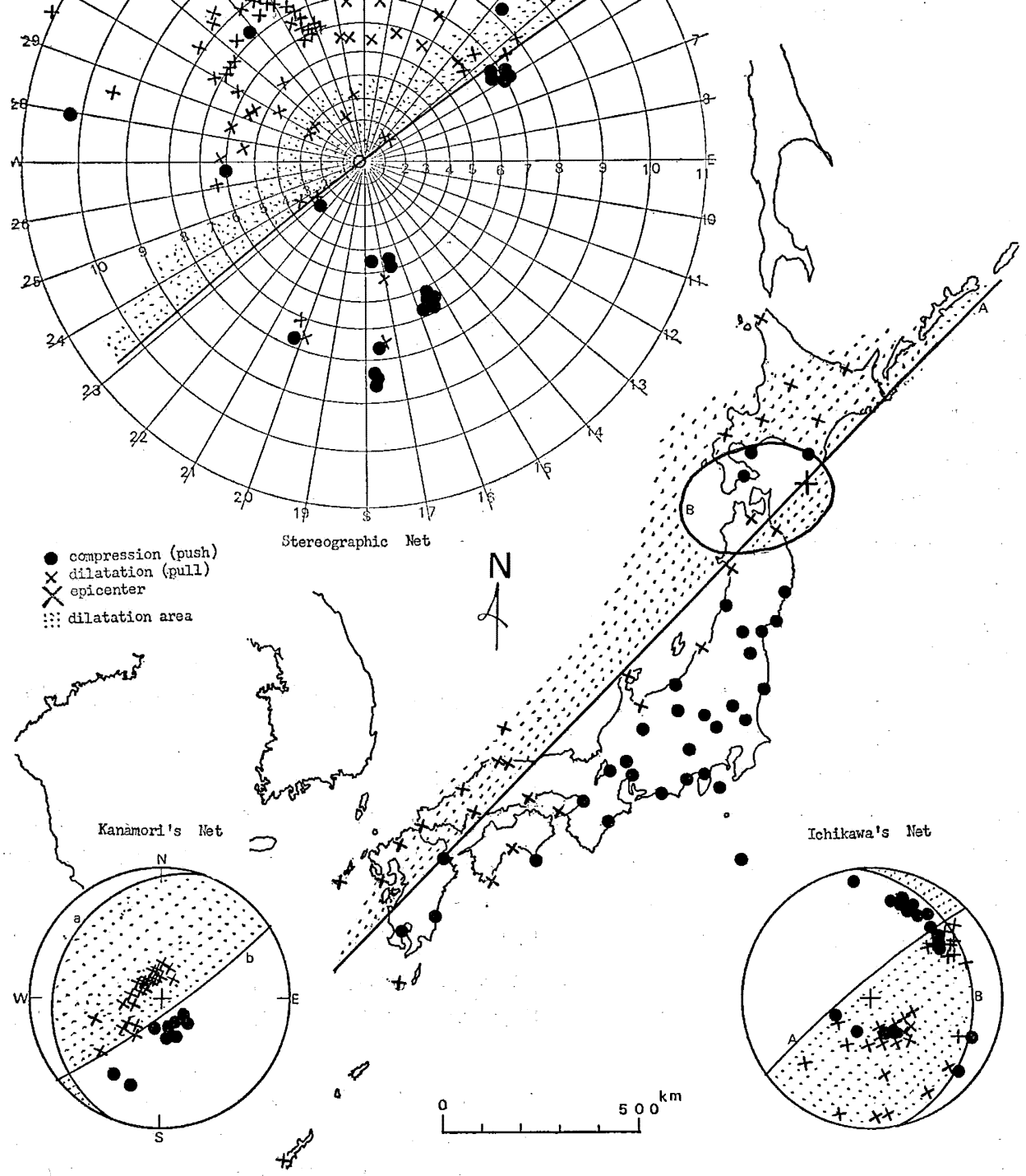

Fig. 3. E Off Aomori Pref. earthquake at about 19 o'clock on May 16, 1968: This earthquake occurred only 10 hours after the Off Tokachi earthq. in Fig. 1. This radiation pattern is quadrant type, but observations at Aomori, Akita, Wazima, Sumoto, Okayama, Koochi, Shimizu, Amamiooshima and Okinawa go against the quadrant type. So this pattern is not quadrant type. 


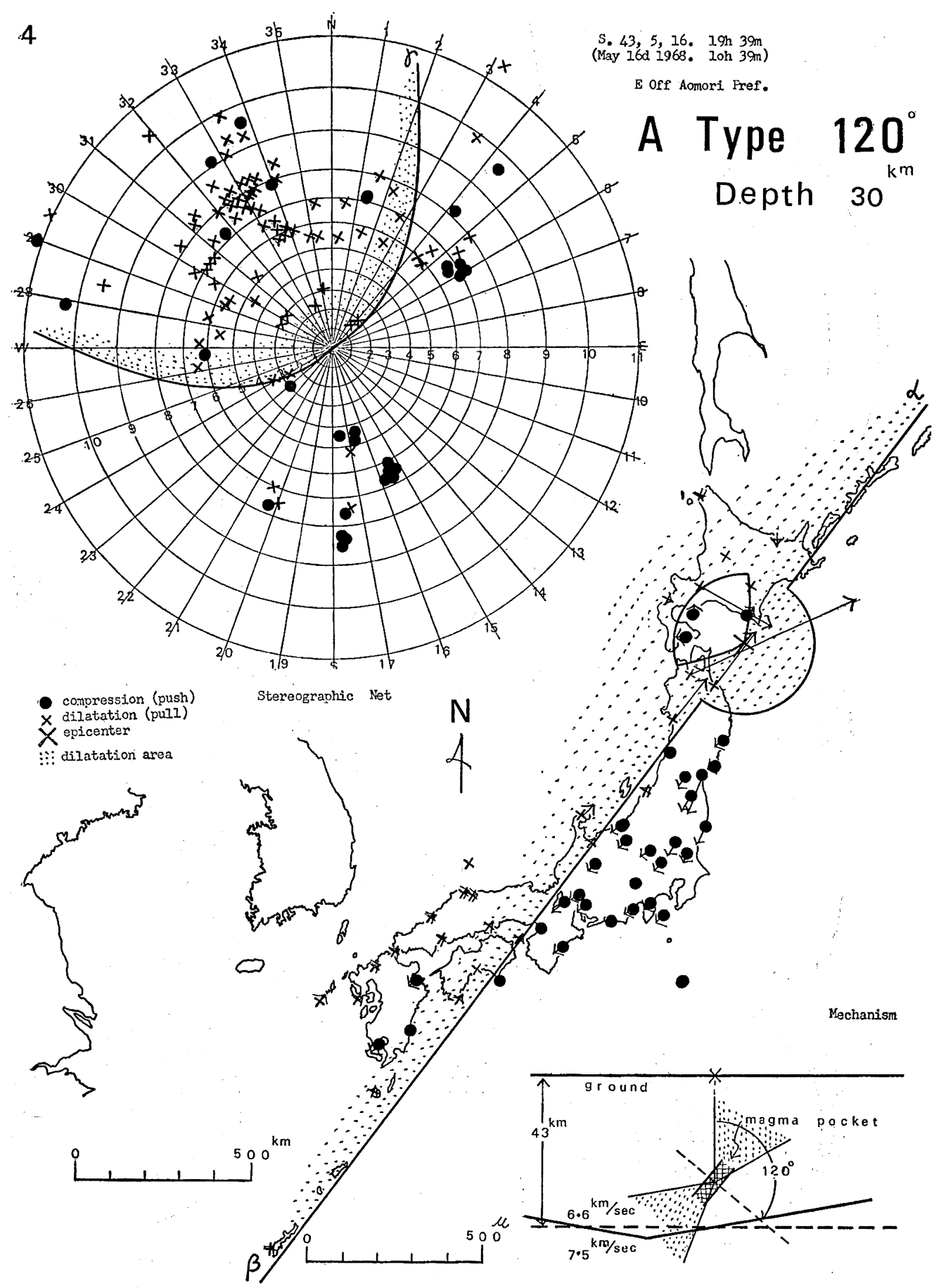

Fig. 4. The same earthquake as in Fig. 3 : This radiation pattern is conical type, and far more excellent than the quadrant one as shown in Fig. 3. The below right figure shows the underground structure for making this pattern. 


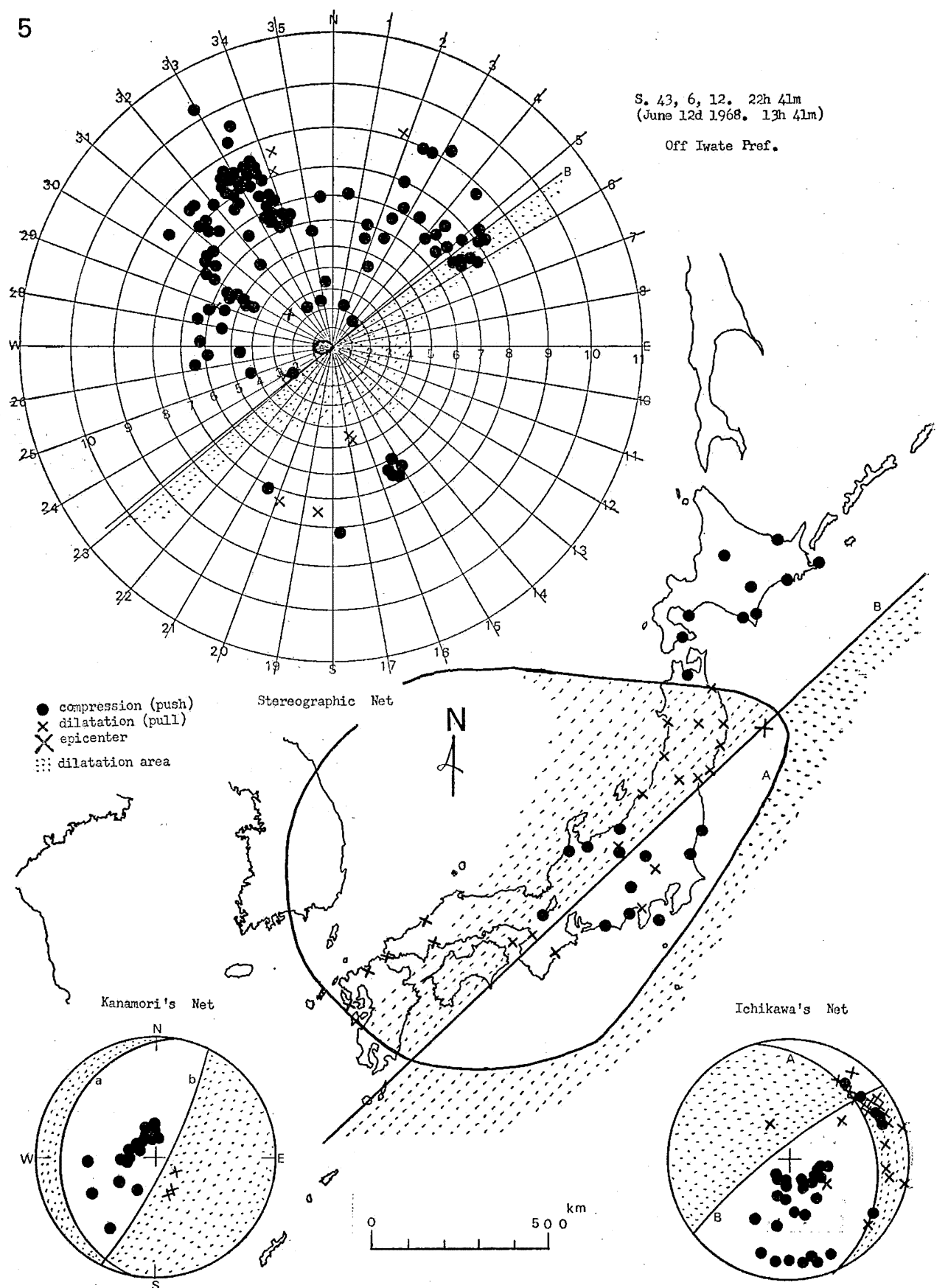

Fig. 5. Off Iwate Pref. earthquake at about 22 o'clock on June 12, 1968: This earthquake occurred four weeks after the Off Tokachi earthqu. in Fig. 1. This radiation pattern is quadrant type, but observations at Takada, Matsushiro, Toyama, Kanazawa, Kyoto and Owase are against the quadrant type. So this pattern is not quadrant type. 


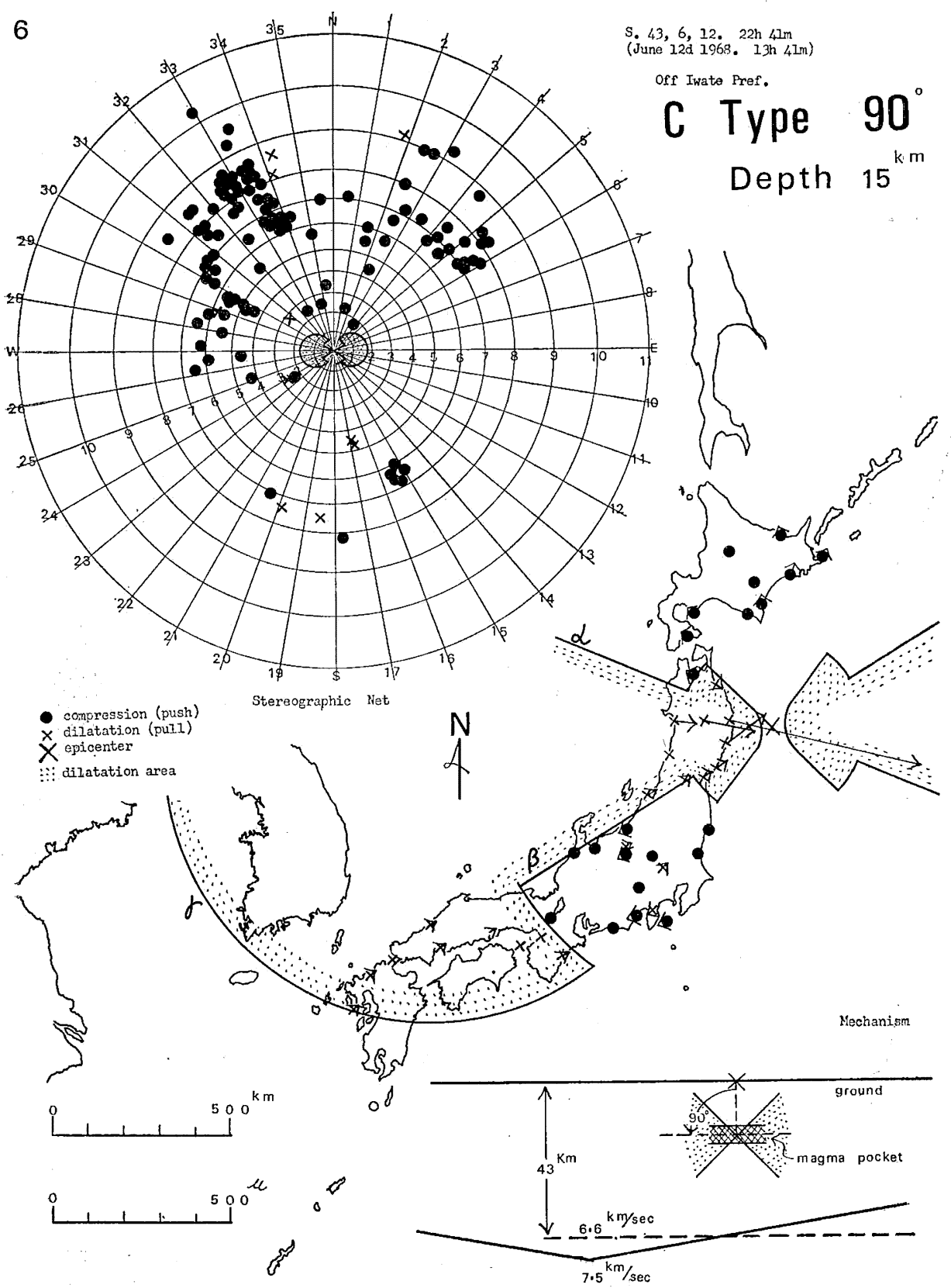

Fig. 6. The same earthquake as in Fig. 5 : This radiation pattern is conical type, and far more excellent than the quadrant one as shown in Fig. 5. 


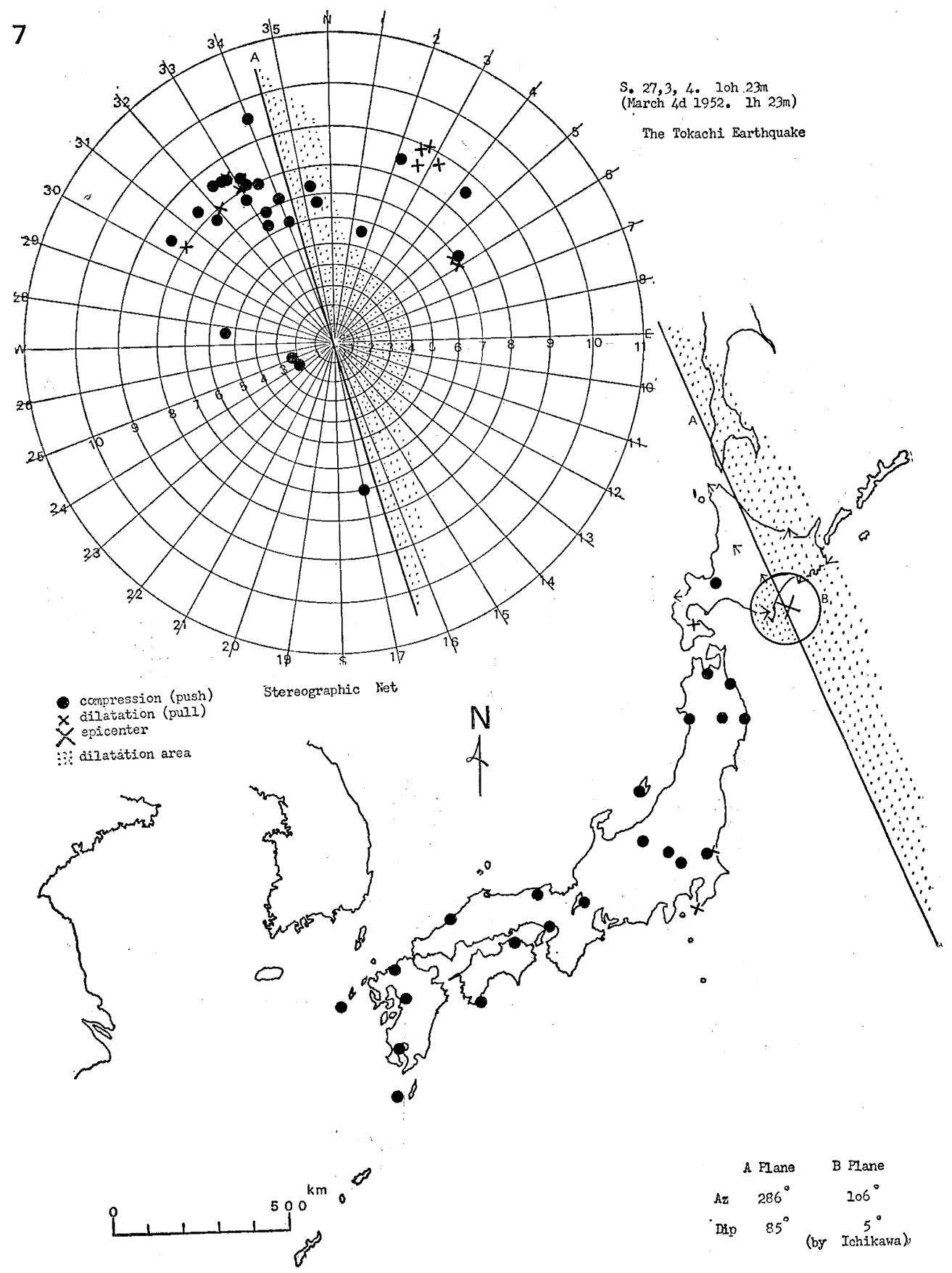

Fig. 7. The Tokachi earthquake at about 10 o'clock on March 4, 1952: A few observations measured the initial motion in the world. This radiation pattern is quadrant type. 


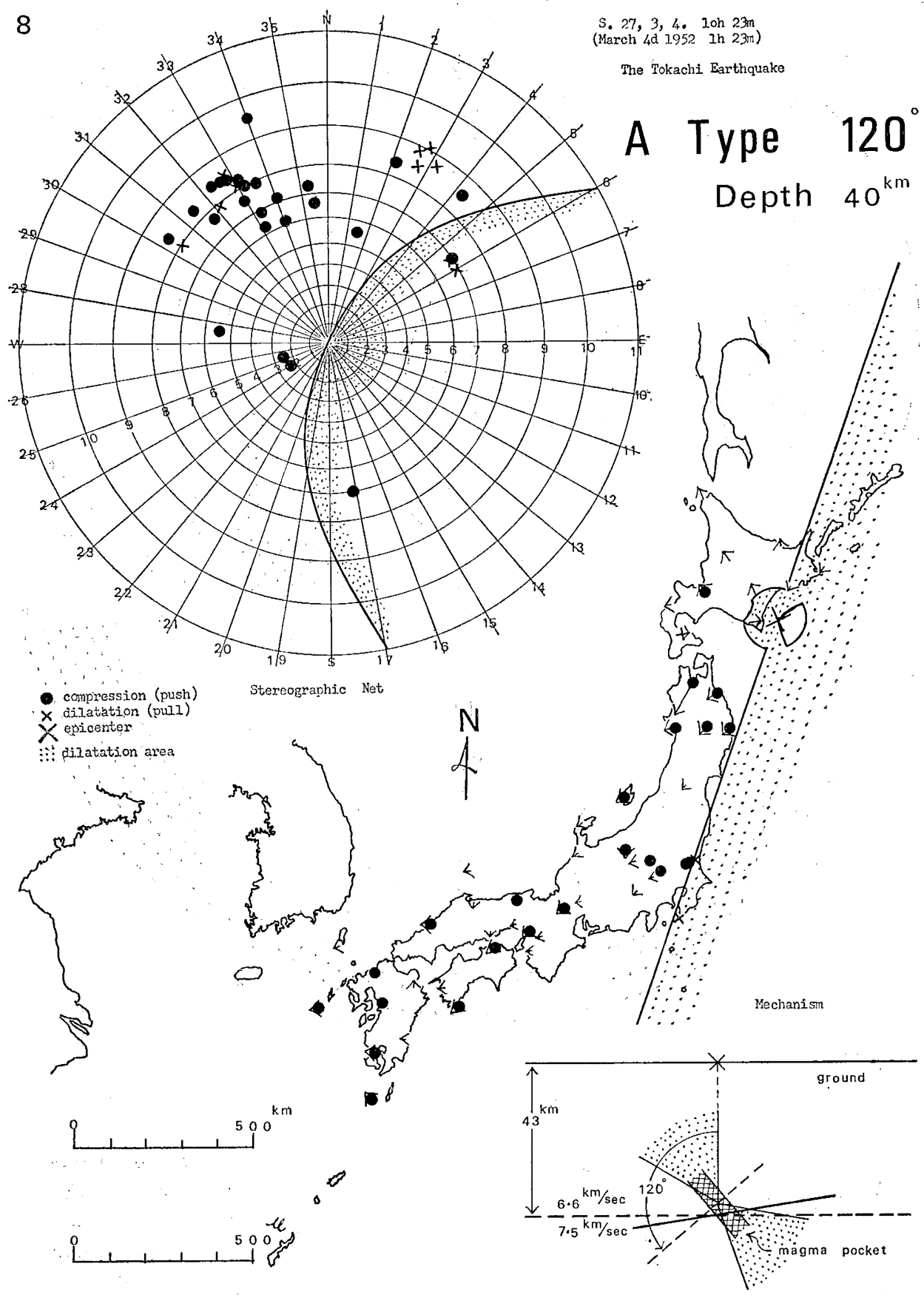

Fig. 8. The same earthquake as in Fig. 7. This radiation pattern is conical type. 
9

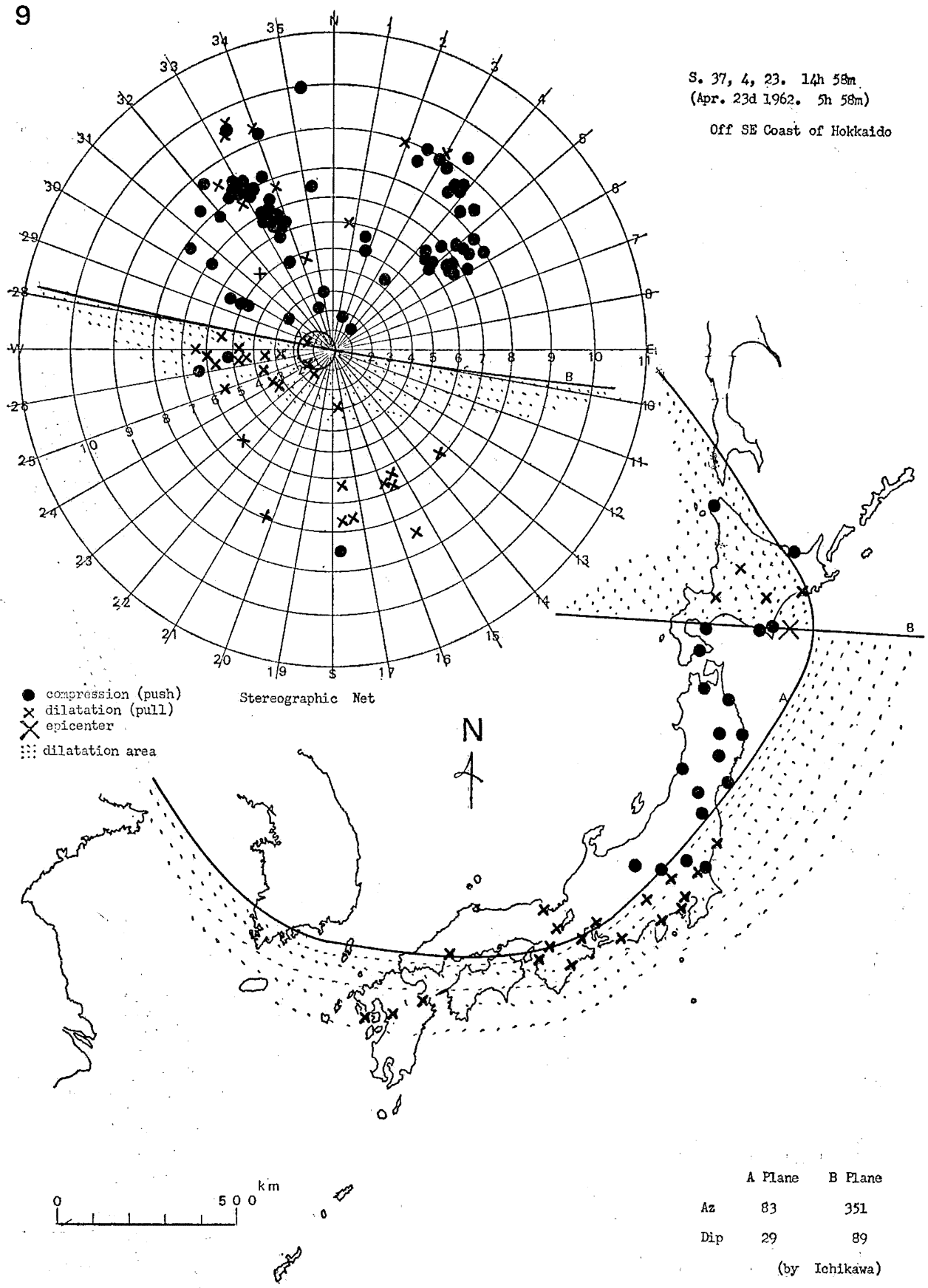

Fig. 9. Off SE Coast of Hokkaido at about 14 o'clock on April 23, 1962: Many observations measured the first motion too late in the world. This radiation pattern is quadrant type, but observations at Wakkanai, Mito, Utsunomiya, Nagoya, Kyoto, Maizuru and Hiroshima are against the quadrant type, so this radiation pattern is not quadrant type. 


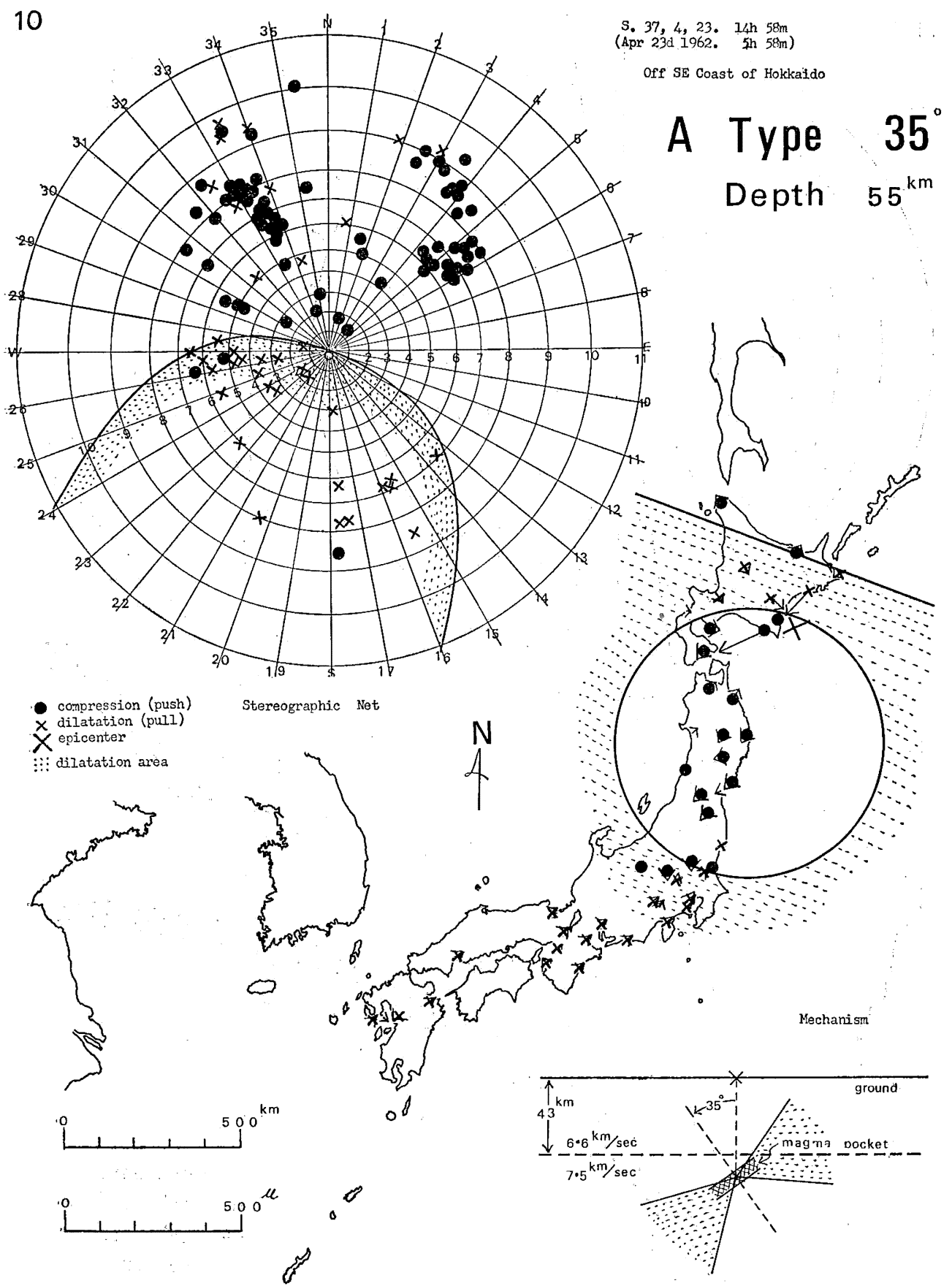

Fig. 10. The same earthquake as in Fig. 9: This radiation pattern is conical type, and far more excellent than Fig. 9. The below-right figure shows the underground structure for making this pattern. 

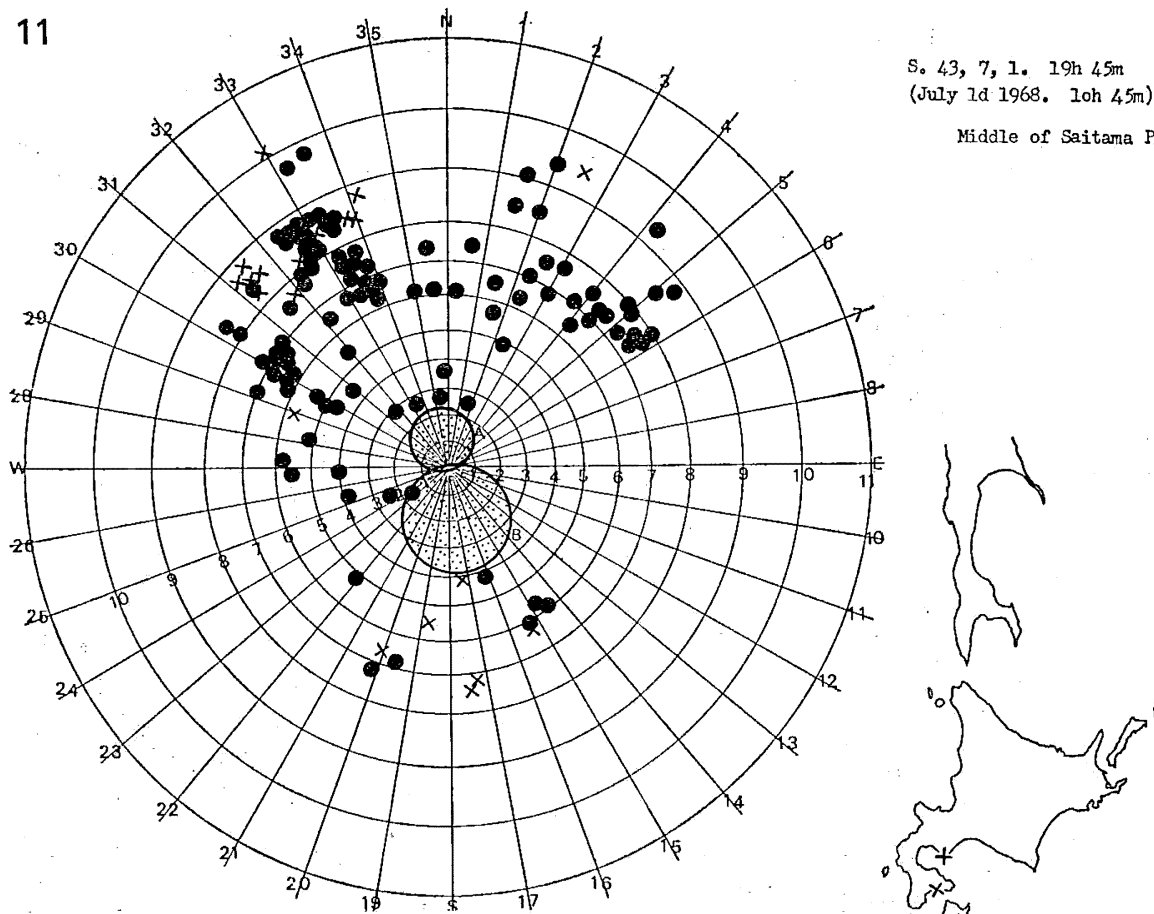

Middle of Saitama Pref.

- compression (push)

$x$ dilatation (puIl)

$X$ epicenter

: $:$ dilatation area

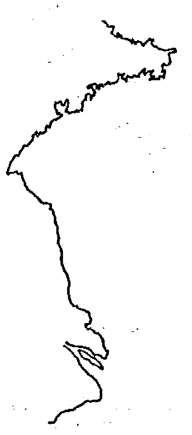

Stereographic let
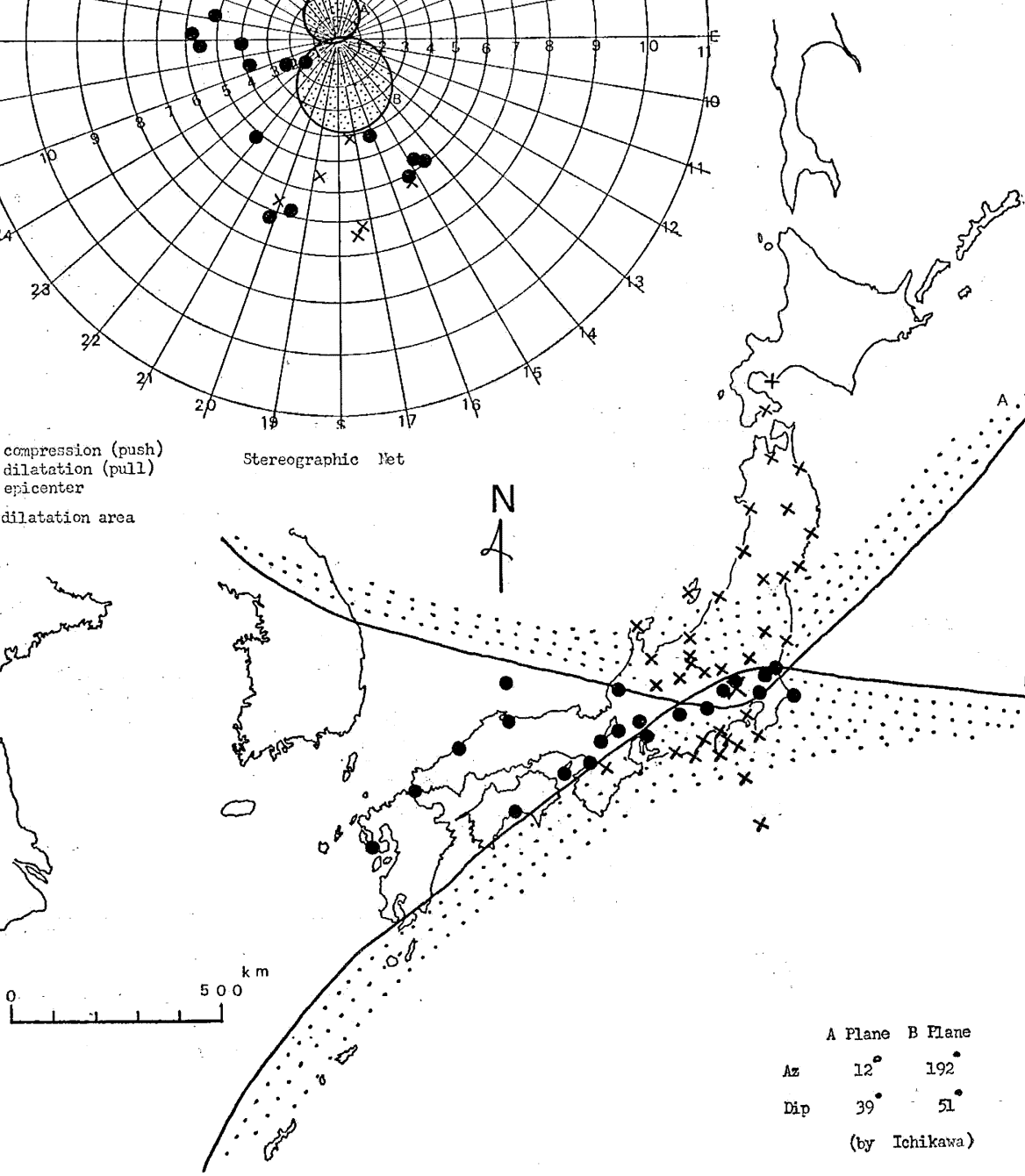

Fig. 11. Middle of Saitama Pref. earthquake at about 19 o'clock on July 1, 1968 : This radiation pattern is quadrant type, but observations at Chyoshi, Koofu, Iida and Nagoya are against the quadrant type, so this pattern is. not quadrant type. 

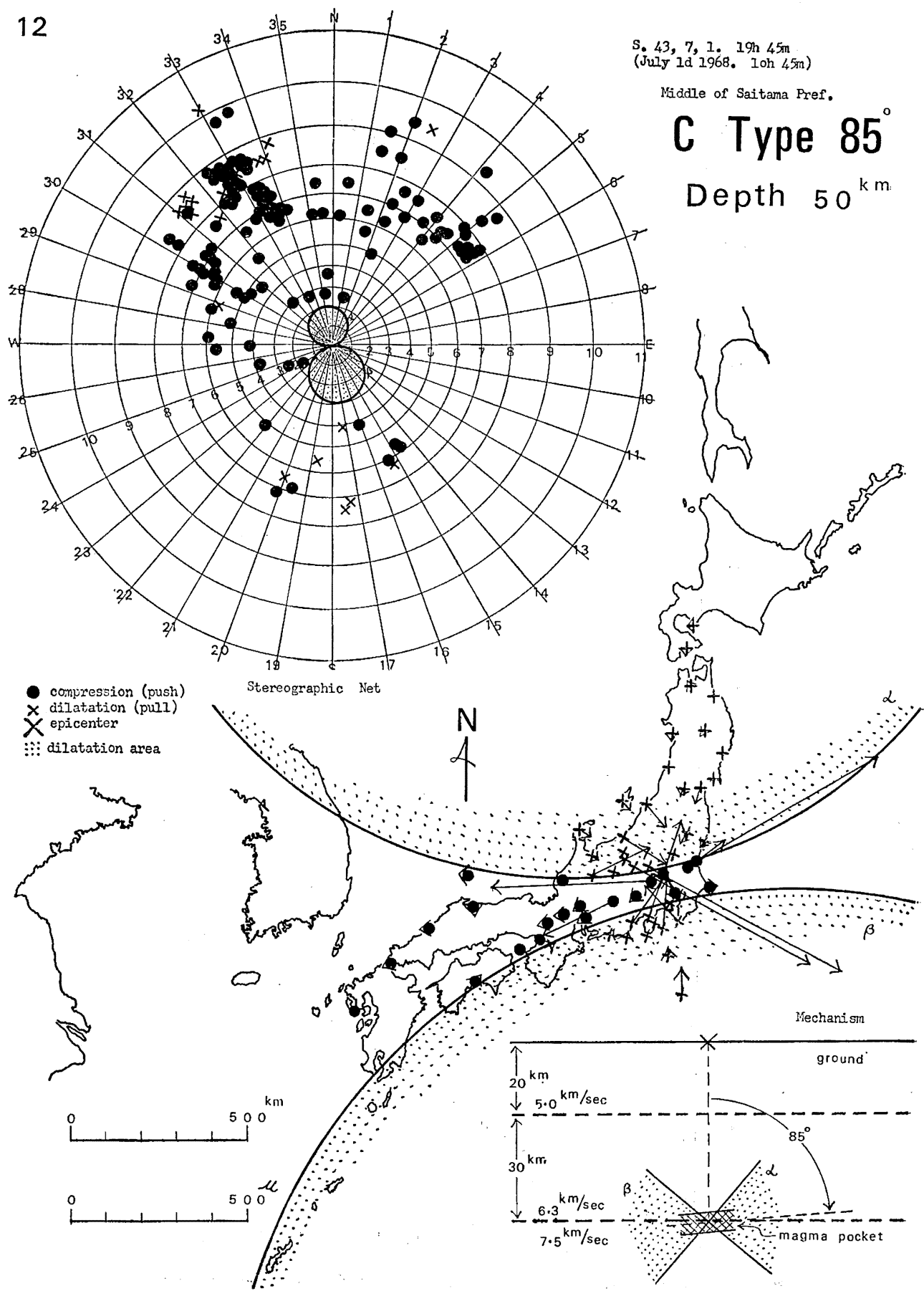

Fig. 12. The same earthquake as in Fig. 11: This radiation pattern is conical type. This is far more excellent than Fig. 11. 

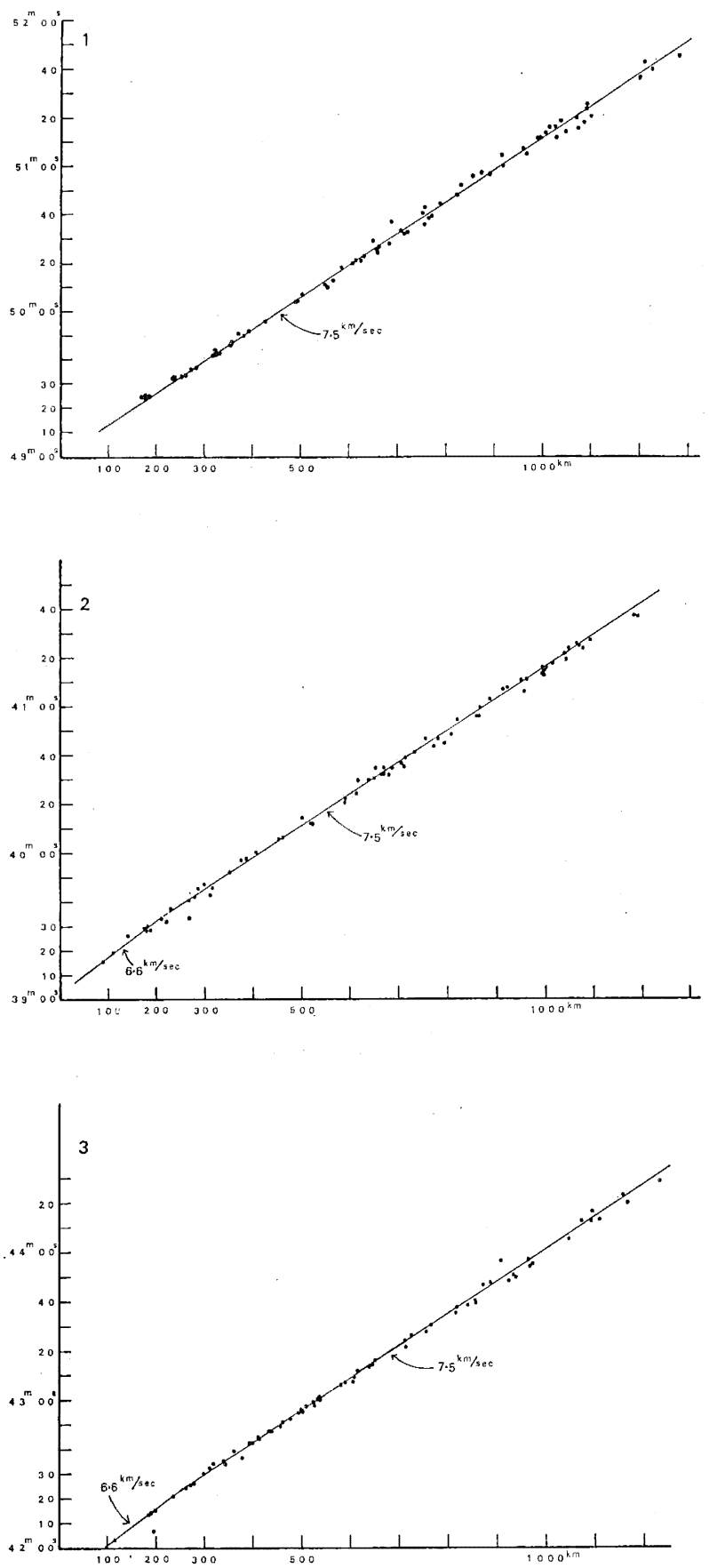

Fig. 13. Travel time distance: 1) The Off Tokachi earthquake at about 9 o'clock on May 16, 1968. 2) E Off Aomori Pref. earthquake at about 19 o'clock on May 16, 1968. 3) Off Iwate Pref. earthquake at about 22 o'clock on June 12, 1968. 
それによって nodal lineを描いたものが，Fig.9 である。この頃になると，外国でも初動分 布の重要性が分ってきたとみえて，かなり多くの初動観測が I.S.C. にも記載されている。そ れが，Fig.9 の左上の stereograph の図である。これも，市川の調查であるが，外国の区分は これでよいとしても，日本付近は，らまく区分されているとは言光ない。震央付近の広尾，根 室, 稚内が区分からはみ出している。同様に関西の舞鶴, 京都もはみ出している。

Fig.10 は，同じ地震を岩しょう爆発型に区分したものである。地震の深さは $55 \mathrm{~km}$ である。 非対称押円錐型の主軸が $35^{\circ}$ 傾いている機構であって，その主軸の方向は，北から時針䢙りに $200^{\circ}$ の方向である。外国の資料は右上の stereograph の図であるが，らをく区分されている。 日本付近も, Fig.9 亿比較すると, 格段の相違である。

したがって,これも，断層型の地震とは言光ない。

Fig. 11 は，昭和43年（1968年） 7 月 1 日19時45分頃に起った埼玉県中部の地震である。地震 の大きさは，北伊豆地震よりすこし小さいていどであった。被害はなかった。この初動分布は， Fig. 12 と比較して見ても分るように, 断層型にはならないのであるが, 市川は無理をして,

Fig.11 のように区分している。銚子，甲府，飯田，名古屋の押波が，区分の中にはいっていな い。しかも，定量的には，二つの節面 A，B が交差する付近である水戸付近や飯田付近は，初 動の大ささが非常に小さくならねばならないが，現象は逆に，かなり大きくなっている。これ は，次に述べる岩しよう爆発型には，つごうのいいことであるが，断層型を否定する結果になっ ている。

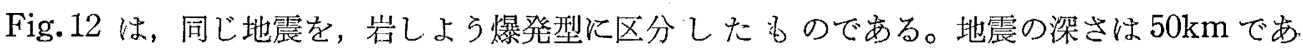
る。一つの例外もなく, ら西く区分されている。これは, 対称引円錐型の主軸が $85^{\circ}$ 傾いている もので，その軸の向きは，時針超りに $350^{\circ}$ である。

以上のように, 十勝沖地震といわれているものは, 大きな地震だけをを取り上げてみても, 詳し く検討すると，断層型地震ではなく，岩しょら爆発型地震であることがわかる。 plate 説による と, 日本海溝は, lithosphere の落も込生所であり, 十勝沖地震は同一傾向の断層型でなくては ならないがそそらなっていないのであるから，plate 説は仮空の学説になってしまった。

\section{3. 地下構造について}

Fig.1, Fig.3, Fig.5 等を説明した時, 断層型に区分しょうという努力にもかかわらず，中 距離の押波と西日本の引波とが，うまく区分できていないことを述べた。また，Fig.2, Fig.4， Fig. 6 を説明した時, 地下構造については, あとで詳しく述べることを約束した。これからそ の説明をするつもりである。

このよらな特别な現象が起る理由として, まず考えられることは, 地下構造によって, このよ らなことが起るのではないかといらことである。それゆ文，まず，それぞれの走時曲線を作って みた。Fig.13の1は，Fig.1 またわ Fig. 2 の十勝沖地震の走時曲線である。これは，1本の 直線の上に乗って牰り, それは, $7.5 \mathrm{~km} / \mathrm{sec} の$ 速度を示している。それゆえ, 転向円が観測に かかっていないことがわかる。また, 西日本の引波の観測されているあたりも, 特別に, 波が早 く出たり，遅く出たりしているわけでもない。Fig.13 の 2 は, Fig.3 またわ Fig.4の青森県 東方沖の地震の走時曲線であり, Fig. 13 の 3 は, Fig. 5 またわ Fig.6 の岩手県沖の地震の走 時曲線である。これらは 2 本の直線からできていて, $6.6 \mathrm{~km} / \mathrm{sec}$ の速度の層の下に, $7.5 \mathrm{~km} /$ sec の速度の層があることがわかる。ほた, 転向円の大きさは, Fig.13の 2 の青 森県東方沖の 
地震は $200 \mathrm{~km}$ であり，Fig. 13 の 3 の岩手県沖の地震は $300 \mathrm{~km}$ である。

これらの地震が起ったあたりの地下構造は, 爆破グループ (1968) が算出したものがあり，そ れによると，深さ $10 \mathrm{~km}$ までは $6.0 \mathrm{~km} / \mathrm{sec} の$ 速度であり，その下 $10 \mathrm{~km}$ までは $6.6 \mathrm{~km} / \mathrm{sec}$,

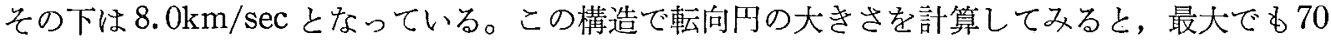
$\mathrm{km}$ であり，この構造では，これらの地震の走時曲線を説明することができない。爆破で求めた 構造も, 自然地震に適用できないのでは, どらにもしようがない。このようなことが起るのは, 爆破地震は非常に波長が小さいので，自然地震のように波長の大きい波とは通る2らが違 らの ではないかとも考光られる。田望（1972）が求めた構造は，地表から $10 \mathrm{~km}$ ぐらいまでは 5.2

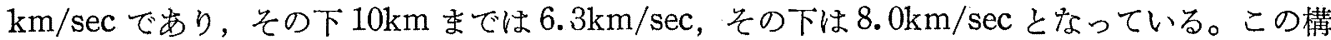

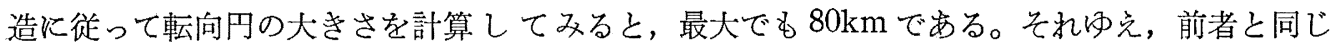
く,これらの地震には適合しない。

それゆ克, これらの自然地震に適合した地下構造を求める必要に迫られた。6.6 km $/ \mathrm{sec} の$ 層 の厚さを $x \mathrm{~km}$ とし，地震の深さを $y \mathrm{~km}$ とし，転向円の半径を $R \mathrm{~km}$ とすると，転向円の所で は，直達波と転向波との到達時間が一致しなければならないから，

$$
\frac{\sqrt{R^{2}+y^{2}}}{6.6}=\frac{R-x \tan \theta-(x-y) \tan \theta}{7.5}+\frac{x \sec \theta+(x-y) \sec \theta}{6.6}
$$

が成立しなければならない。ここに $\theta$ は臨界角であって,

$$
\sin \theta=\frac{6.6}{7.5} \quad\left(\theta=61^{\circ} 39^{\prime}\right)
$$

である。

$R=200 \mathrm{~km}$ とすると, $x, y$ の関係は Table 2 となり， $R=300 \mathrm{~km}$ とすると, $x, y$ の関係は Table 3 となる。

Table 2. Relation of $x$ and $y_{1}$, case $R=200 \mathrm{~km}$

\begin{tabular}{c|cccccc}
\hline \hline $\begin{array}{c}y_{1} \mathrm{~km} \text { (地震の深さ) } \\
\text { Depth of Earthq. }\end{array}$ & 0 & 10 & 20 & 30 & 40 & 50 \\
\hline $\begin{array}{c}x \mathrm{~km} \text { (層の厚さ) } \\
\text { Thickness of Layer }\end{array}$ & 25.2 & 30.4 & 36.3 & 42.5 & 49.5 & 56.9 \\
\hline
\end{tabular}

Table 3. Relation of $x$ and $y_{2}$, case $R=300 \mathrm{~km}$

\begin{tabular}{c|cccccc}
\hline $\begin{array}{c}y_{2} \mathrm{~km} \text { (地震の深さ) } \\
\text { Depth of Earthq. }\end{array}$ & 0 & 10 & 20 & 30 & 40 & 50 \\
\hline $\begin{array}{c}x \mathrm{~km} \text { (層の厚さ) } \\
\text { Thickness of Layer }\end{array}$ & 39.9 & 43.2 & 48.6 & 54.5 & 60.8 & 67.0 \\
\hline
\end{tabular}

\begin{tabular}{|c|c|c|c|c|}
\hline $\begin{array}{l}x \mathrm{~km} \text { (層の厚さ) } \\
\text { Thickness of Layer }\end{array}$ & 38 & 43 & 48 & 55 \\
\hline $\begin{array}{l}y_{1} \mathrm{~km} \text { ( } 5 \text { 月 } 16 \text { 日の地震の深さ) } \\
\text { Depth of Earthq. of May } 16\end{array}$ & 22 & 30 & 38 & 47 \\
\hline $\begin{array}{l}y_{2} \mathrm{~km} \text { ( } 6 \text { 月 } 12 \text { 日の地震の深さ) } \\
\text { Depth of Earthq. of June } 12\end{array}$ & 0 & 10 & 20 & 30 \\
\hline
\end{tabular}

Table 4. List of $y_{1}$ and $y_{2}$ for $x$ 
そこで, 層の厚さ $x$ と， 2 つの地震の深さ $y$ との関係を並べてみると, Table 4 となる。

これらの内， $x=43 \mathrm{~km}$ とするのが妥当のように思える。 $x=38 \mathrm{~km}$ とすると， $y_{2}=0$ となり， これより浅い地震に適用でさなくなる。 $x=55 \mathrm{~km}$ とすると，大陸の Mohorovicic 層の厚さ50 $\mathrm{km}$ より厚くなる。 $x=48 \mathrm{~km}$ としてもよいのであるが，なるべく $x$ を薄く取ることにして， $x=43 \mathrm{~km}$ とした。

それゆ光，地下構造は Fig. 14 となる。

この構造のもとで, 地震の深さ $y$, 転向円の半径 $R$ との関係は, (1) 式の $x$ を $43 \mathrm{~km}$ として 計算し, Fig.15 となる。

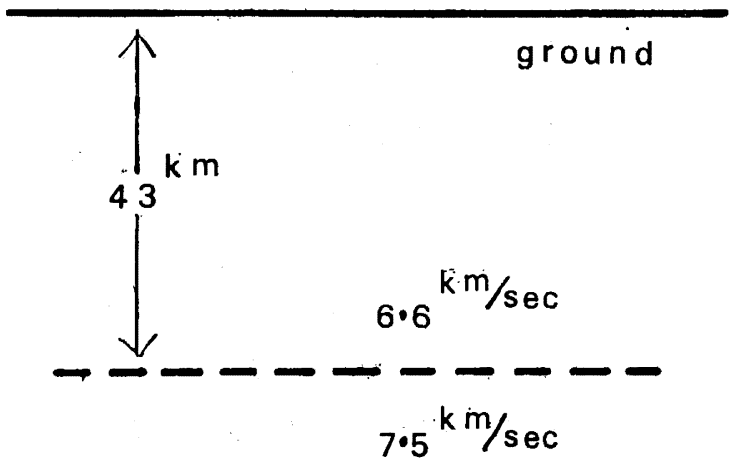

Fig. 14. Underground structure.

この計算結果を用いて，昭和43年（1968年） 5 月16日 9 時48分の十勝沖地震の深さを求める。 この地震の走時曲線 (Fig.13の1) には, $6.6 \mathrm{~km} / \mathrm{sec}$ の線がないので, 転向円は観測にかから なかったと思われる。震央に一番近い観測点の震央距離は $150 \mathrm{~km}$ ぐらいであるから，もし転向 円があったとしても，その半径は $150 \mathrm{~km}$ 以下である。この条件を満足するように，この地震の 深さを Fig. 15 から求めると，35km 以上となる。しかし，初動分布の形から，この地震は 6.6 $\mathrm{km} / \mathrm{sec}$ の層中の地震であることは明白であるから, 地震 の深さは $35 \mathrm{~km}$ から $40 \mathrm{~km}$ ぐらいま でである。ここでは, 一応, 地震の深さは $40 \mathrm{~km}$ とした。

この地下構造のもとで, 初動分布を作図すると, 転向円外の姿勢を保つのは, 震央距離が 700 〜 800km ぐらいまでで，それ以上は臨界角以下に射出された波が現われるはずである。ところ が, 700 1, 500km ぐらいの所に，問題の西日本の引波が現われている。これは，普通では起 り得ないことであり，また，考觉られないことである。何か特別な事情によるのではないかと考 えられる。偶然にも，久本壮一(1965) も，同じぐらいの震央距離のあたりに， S 波の異常に早 く出現する現象を発見しているので，同じ事情によるのではないかと思ったが，久本のは S 波で あり，筆者のはP波であるから，同じ事情とは考兄られない。久本の現象は, 久本自身は記述し ていないが，S波が異常に早く現われる部分は, 地震の起らない所を通って来た波であり，S波 の遅く現われる部分は, 地震の巣を通って来た波であることから, 地震の巣（地震のよく起る部 分）には，岩しょう溜が多数存在し，ここを通るS波は，波長の小さいものは吸収されるので， その分だけS波の出現が達れたものと考兄られる。方，地震の起らない所を通って来たS 波 は, 岩しよう溜で吸収されることがないので, その出出現し, 早く到達したように観測された ものと思われる。その証拠として，P波の方は, 異常に早く出現する部分がないことである。や 


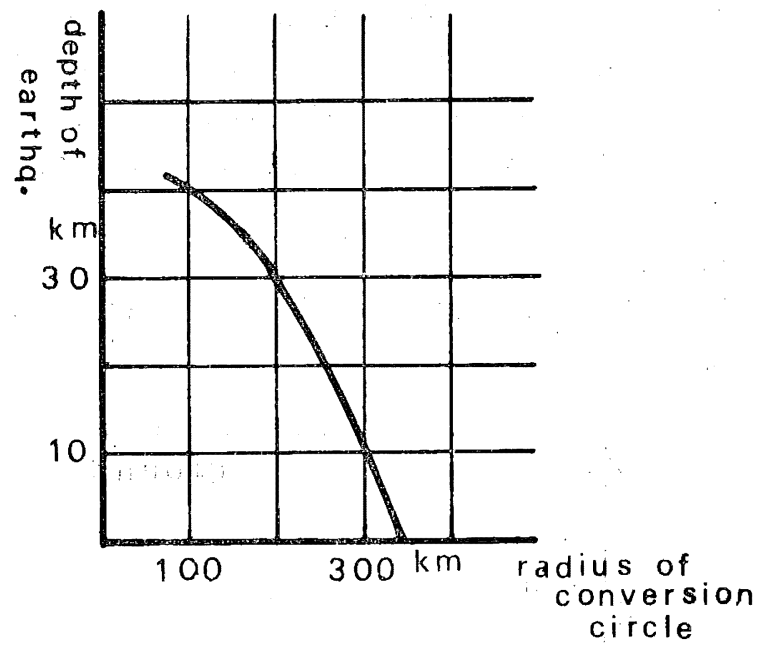

Fig. 15. Relation between depth of earthquake and radius of conversion circle.

はり，地震は岩しょう作用によって起っているものと考学らるる。

そこで, 地震波の射出角と発震機構との関係をしらべてみよう。Fig.16の1 は Fig. 2 に対す

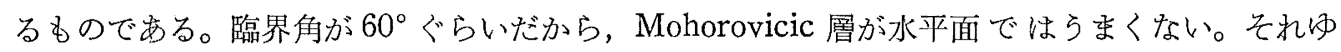
壳, 観測に合らように, 震源直下の Mohorovicic 層は $10^{\circ}$ 西方へ傾斜しているものと考兄られ る。そらすると，転向円を形成する円は，円ではなく，図の実線の楕円となる。ごれで東北地方 と北海道の押波の部分は，与まく区分される。この効果は, 震央距離 $700 \mathrm{~km}$ ぐらいまでであ る。それから $1,500 \mathrm{~km}$ までは, 本来ならば, 射出角が $130^{\circ} \sim 135^{\circ}$ の波が到達する部分である が，Fig.16の1図に見るように，そのあたりは押波の出る部分であって，引波は出ない。しか 乙，実際には，引波が観測されている。それゆえ，もし，引波が出るとすれば，射出角 $110^{\circ} \sim$ $120^{\circ}$ の部分の引波が出ていると考光なければならない。Fig.16 の1図の太い×印の引波であ る。しかし，この部分は，普通，全反射する部分であって，震央距離 $700 \mathrm{~km} \sim 1,500 \mathrm{~km}$ に出現 することはない。これが出現するためには，射出角 $110^{\circ} \sim 120$ 。にあたる Mohorovicic 層の下 面が，東へ $10^{\circ}$ 傾斜している必要がある。この Mohorovicic 層の下面の凸凹が，Fig.2 の右下 の図に記入してある。このような構造になっていると，転向円を形成する棈円がもら一つでき る。それが Fig.16の1 には，破線の棈円になっている。実線の棈円と破線の楕円とに囲われた 引波の部分が，西日本の引波として出現する。そらすると，Fig.2 の中央の図のように，初動 分布は区分される。こうして, この地震の初動分布は, 岩しょら爆発説の立場からは, 一つの例 外もなく，きれいに区分された。しかし，断層説の立場からは，どらにも解決できない現象であ る。

Fig.16 の 2 は，Fig. 4 に対するものである。詳しい説明は，前者と同じであるので，省略す る。地下構造は, Fig.4 の右下に記入してめる。

Fig. 16 の 3 は，Fig. 6 亿対するものである。太い×印の部分が西日本に出現する部分であ る。地下構造は Fig. 6 の右下に記入して执いた。 


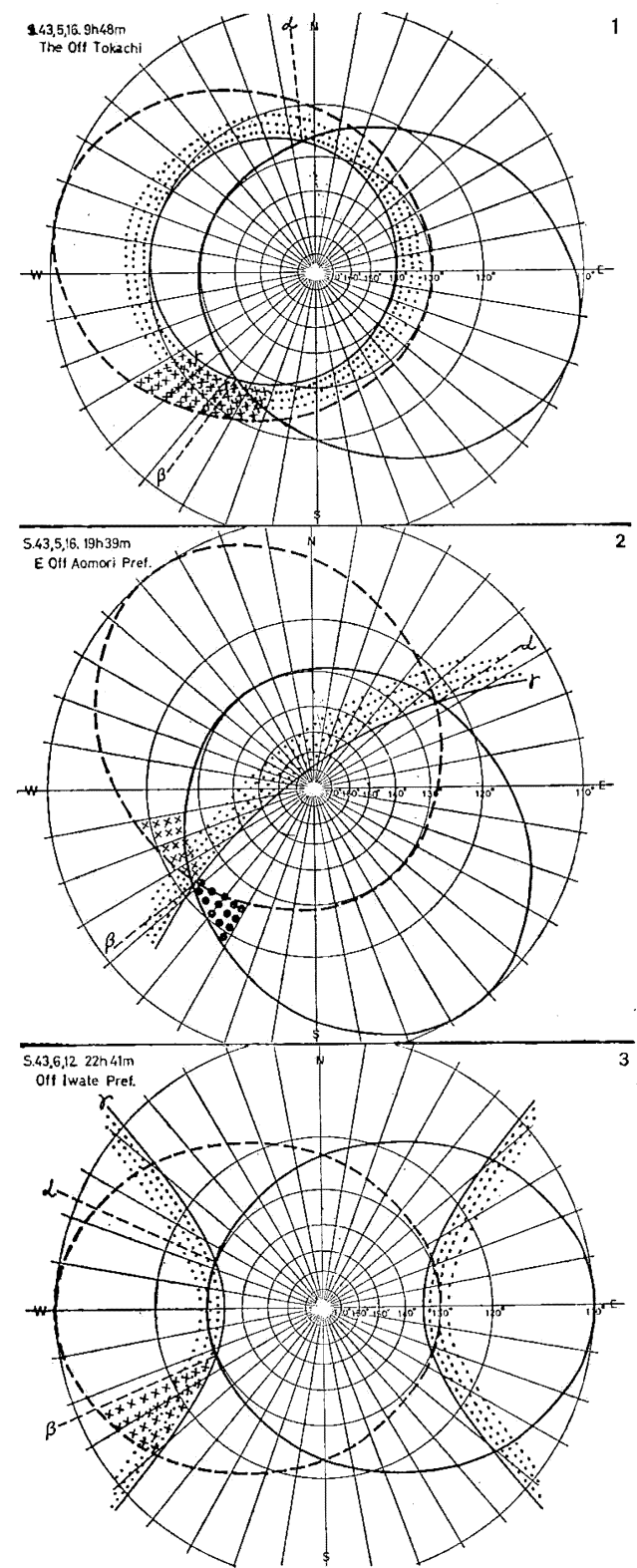

Fig. 16. Relation between emergent angle and conversion circle: 1) Case of the Off Tokachi earthqu. at about 9 o'clock on May. 16, 1968. 2) Case of E Off Aomori Pref. earthqu. at about 19 o'clock on May 16, 1968. 3) Case of Off Iwate Pref. earthqu. at about 22 o'clock on June 12, 1968. 
このような地下構造になっていると, 初動の大きさが非常に小さくなる。これらの地震より は，ずっと規模の小さい Fig.12.の初動の大きさと比較すると，よくわかると思う。

\section{4. 発震機構について}

昭和 43 年 5 月 16 日 9 時 48 分の十勝沖地震は, Fig. 2 の初動分布によると, 地下 $40 \mathrm{~km}$ に存在 する岩しょう溜内の爆発によって起ったものである。この岩しょう溜は, 東へ $10^{\circ}$ 傾斜した岩 脈型である。

昭和43年 5 月 16 日19時39分の青森県東方沖の地震は, Fig.4 の初動分布によると, 地下 $30 \mathrm{~km}$ に存在する岩しょう溜内の爆発によって起ったものである。この岩しょら溜は, 西へ $60^{\circ}$ 傾斜 した岩脈型である。

昭和43年 6 月 12 日22時41分の岩手県沖の地震は, Fig. 6 の初動分、布によると, 地下 $15 \mathrm{~km}$ に 存在する岩しょう溜内の爆発によって起ったものである。この岩しょう溜は, 円筒型で水平に貫 入している。

これらの地震は, 短期間に, ひき続き起ったが, 距離的に離れていることと, 岩しよう溜の型 等から，直接的なつながりはないと思う。plate 説によるとこれらの地震は規則性を持たなけ ればならないが，規則性はない。したがって，plate説は現象によって否定されている。松沢武 雍 $(1966,1968)$ も遠方力による地震説は理論的に否定している。

Fig. 8 は, 昭和 27 年 3 月 4 日 10 時 23 分の十勝地震である。深さ $40 \mathrm{~km}$ である。初動分布はFig. 4 と対蹠的になっている。この場合は，岩しょう溜は東に $60^{\circ}$ 傾斜した岩脈型である。この中 で爆発が起って生じた地震と考学られる。

Fig. 10 は, 昭和37年 4 月 23 日 14 時58分の北海道東南岸沖の地震である。深さは $55 \mathrm{~km}$ である から, Mohorovicic 層を考える必要がない。この地震の岩しょう溜は, 西に $35^{\circ}$ 傾斜した岩脈 型である。この中の爆発によって起った地震と考光られる。

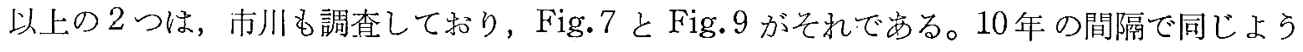
な所に起った地震であるが，率層の傾向は，互に直交していて，断層説からみても，規則珄が見 られない。

Fig. 12 は, 昭和 43 年 7 月 1 日 19 時45分の埼玉県中部の地震である。深さは $50 \mathrm{~km}$ であるが, Mohorovicic 層の影響を考皇ないでよい初動分布になっている。岩しょう溜は西に5゚傾斜した 円筒型である。この中の爆発によって起った地震と考光られる。

\section{5. 総 括}

初動分布を区分する場合，4象限型に区分するよりは，円錐型に区分した方が，はるかに，現 象に忠実であることを, 十勝沖地震を例に取って詳しく説明した。4 象限型が不忠実であること は，地震は断層の生成によって起こるものでないことを，証明している。このことは，また， plate 説等を否定することになる。これらの説に対し，いくら他に多くの有利な係類的現象があ ったとしても，初動分布が説明できない場合は，これらの説が地震と関係がある，とは言えな い。現象は岩しょら爆発説に有利であった。しかも, こまかい内部構造を考觉にいれるところま で進展してきた。

全世界の資料を用いて初動分布を調査する時は, stereograph に記入するのが便利である。 I.S.C. の資料には, $\mathrm{Az} z^{\circ}$ (方向) と $\Delta^{\circ}$ (距離) が報告されているので, 記入するのが簡単で, 
しかも，実体的になっているので，思考上有利である。Wulf Net を用いると，多数で小数を 制压することになり，本文で例示したように，真実を見失う結果になりやすい。

射出角と震央距離との関係は，近い所は，市川政治等（1971）の走時表を用い，遠い所は， J.H.HODGSON (1953) の走時表を用いた。この調査の過程に掞いて, 市川政治の絶大な協力を 仰いだ。ここに記して，感謝の意を表します。そのほか，田望拉よ゙゙長宗留男の助力を仰いだ。 あわせて感謝の意を表します。いつものことながら，気象庁の観測網とその観測の正確さには， 心を打たれるものがあった。ここに記して強調したい。

\section{参 考 文 献}

DEN, N., 1972: Explosion seismology. Crust and upper mantle of the Japanese area, 57-68.

Hashizume, M., et al., 1968: Crustal structure in the profile across the North-eastern Part of Honshu, Japan, as derived from explosion seismic observations. Part 2. Crustal structure, Bull. Earthq. Res. Inst., 46, 607-630.

Hodgson, J. H. and R. S. Storey, 1953: Table extending byerly's fault plane techniques to earthquakes of any focal depth. Bull. Seismol. Soc. Am., 43, 49-61.

KANAMORI, H., 1971: Focal mechanism of the Tokachi-Oki Earthquake of May 16, 1968; contortion of the lithosphere at a junction of two trenches. Tectonophysics, 12, 1-13.

Yamakawa, N., M. Kishio, and I. MAEDA, 1972: Aftershocks of the Tokachi-Oki earthquake of 1968 (II). Geophys. Magaz., 36, 53-73.

久本荘一，1965：東日本にあらわ秃る S 波の著しい異常走時について．地震，18，142-153，195-203.

市川政治, 1969: 1968年十勝沖地震調查報告. 気象庁技術報告, 68, 6-20.

市川政治, 望月英志, 1971：近地地震用走時表について. Pap. Met. Geophys., 22, 229-290.

松沢武雄, 1966: 円柱を含み遠方打を受ける弾性体の二次元ひずみの問題. 東京家政学院大学紀要, 6, 1-17. 一, 1968: 大地震の続発. 東京家政学院大学紀要, 8, 87-98. 


\section{十勝沖地 震を批判する}

高 木 聖

十勝沖地震は, 起こった場所が，日本海等の西側であったから，いろいろな問題を含んでいた。今，流行 の plate 説（断層説の 1 種）等に対しては，説の適否関する重要な知見をもたらすものと言克る。これら の説によれば，この辺に起こる地震は，海溝に直角方向の玨縮力によって起こることになっている。しか し, 本調查に上れば, 十勝沖地震は, 断層型の初動分布を示さないで, 岩しょら爆発型の初動分布であっ た。それゆ光，plate 説等は仮空の小説に過ぎないことが，はっきりした。

Fig. 1，Fig. 3，Fig. 5，Fig.7，Fig.9，Fig.11 等は，無理に断層型に区分された初動分布であり，同じ ものを，岩しょら爆発型に区分すると，それぞれ，Fig. 2，Fig.4，Fig.6，Fig. 8，Fig.10，Fig. 12 となる。 比較してみると，格段の差があることがわかる。 